\title{
Chapter 9 \\ Climate Change and Seed Systems of Roots, Tubers and Bananas: The Cases of Potato in Kenya and Sweetpotato in Mozambique
}

\author{
Monica L. Parker, Jan W. Low, Maria Andrade, Elmar Schulte-Geldermann, \\ and Jorge Andrade-Piedra
}

\subsection{The Significance of RTB Crops for Food and Income Security Under Climate Change}

Throughout the humid African tropics, root, tuber and banana (RTB) crops are the most important food staple. Approximately 300 million people in developing countries depend on RTB value chains (namely cassava, potato, sweetpotato, bananas and yams) for food security and income (Thiele et al. 2017). Indeed, foods derived from RTB crops contribute significantly to caloric needs, from nearly $25 \%$ in Nigeria to close to $60 \%$ in the Democratic Republic of Congo (RTB 2016). Being bulky and perishable, RTB crops are commonly grown for local consumption (Bentley et al. 2016).

The potential of RTB production to contribute to food security in sub-Saharan Africa (SSA) has not yet been realized due to low productivity. Underdeveloped seed systems have been unable to disseminate clean seed of climate-smart varieties of RTB crops. Potato yields in most of SSA have stagnated at 8-15 t/ha, largely as a consequence of limited access to quality seed (Demo et al. 2015). In Kenya, Uganda and Ethiopia, nearly $75 \%$ of the potato fields are contaminated with

M. L. Parker $(\bowtie) \cdot$ J. W. Low $\cdot$ E. Schulte-Geldermann

CGIAR Systems Organization Research Program on Roots, Tubers and Bananas (RTB) and International Potato Center (CIP), Nairobi, Kenya

e-mail: m.parker@cgiar.org; j.low@cgiar.org; e.schulte-geldermann@cgiar.org

M. Andrade

CGIAR Systems Organization Research Program on Roots, Tubers and Bananas (RTB),

International Potato Center (CIP), Maputo, Mozambique

e-mail: m.andrade@cgiar.org

J. Andrade-Piedra

CGIAR Systems Organization Research Program on Roots, Tubers and Bananas (RTB),

International Potato Center (CIP), Lima, Peru

e-mail: j.andrade@cgiar.org

T. S. Rosenstock et al. (eds.), The Climate-Smart Agriculture Papers,

https://doi.org/10.1007/978-3-319-92798-5_9 
Ralstonia solanacearum (a long surviving, soil-borne bacterial pathogen), and less than 5\% of farmers have access to quality seed (Gildemacher et al. 2009). However, rates of food production can double, and possibly triple, without expanding the area under production, by developing seed systems that deliver abiotic and biotic stresstolerant varieties.

We present two case studies that describe the introduction of climate-smart varieties of potato in Kenya and orange-fleshed sweetpotato (OFSP) in Mozambique, and the associated challenges in their delivery through seed systems.

\subsection{Challenges to RTB Seed Systems}

Unlike true seed crops, RTB crops are vegetatively propagated crops (VPCs) and their seed systems have received limited investment. Since VPCs tend to remain true to varietal type for generations, farmers tend to save seed over several years. However, there is a problem with this approach; multiplying the VPC seed without acquiring fresh seed to flush through diseased stock can risk degeneration-the process when pests and diseases accumulate over successive cycles of propagation (Bentley et al. 2016). More efficient seed systems that deliver climate-smart varieties and reduce the spread of disease are required to reduce the yield gap in RTB crops.

As shown in Table 9.1, there are challenges to encouraging investment along RTB seed systems, such as the bulky and perishable nature of the planting material. Investment must therefore be focussed near the seed users who are often in isolated, rural areas. Furthermore, the low multiplication ratios mean seed production is more expensive and requires more time than for grain crops.

The benefits of climate-smart varieties can only be realized by addressing weaknesses in the delivery chain through functioning seed systems, directly linking seed systems as a key tool to address climate change. The complexity of the production and logistics systems must also be expertly addressed in order to speed up the delivery of well adapted varieties to markets.

\subsection{Case Studies}

\subsubsection{Improving Access to Quality Seed of Climate-Smart Potato Varieties in Kenya}

Potato (Solanum tuberosum L.) is a key staple and fast expanding commercial crop in SSA with more than 1.6 million hectares under production and five million potato farmers (FAOSTAT 2017). In SSA and other tropical regions, potato production is limited to the cooler highlands that lie between 1600 and $3000 \mathrm{~m}$ above sea level (masl), and where night temperatures drop below the $16-18{ }^{\circ} \mathrm{C}$ required for 
Table 9.1 Key characteristics of propagation material of potato and sweetpotato, as compared to maize

\begin{tabular}{|c|c|c|c|}
\hline Characteristics & Maize & Potato & Sweetpotato $^{g}$ \\
\hline $\begin{array}{l}\text { Consumed plant } \\
\text { part }\end{array}$ & Seeds & Tubers & Roots \\
\hline $\begin{array}{l}\text { Most common } \\
\text { propagation } \\
\text { material }\end{array}$ & Seeds & Tubers & Vine cuttings \\
\hline $\begin{array}{l}\text { Multiplication } \\
\text { ratio }\end{array}$ & $1: 300$ & $1: 7.5-10$ & $\begin{array}{l}1: 3 \text { (a vine may yield } 2 \text { or } 3 \\
\text { cuttings } 30 \mathrm{~cm} \text { long) }\end{array}$ \\
\hline Bulkiness & $20 \mathrm{~kg} / \mathrm{ha}$ & $2000 \mathrm{~kg} / \mathrm{ha}^{\mathrm{b}}$ & $\begin{array}{l}\text { Approx. } 666 \mathrm{~kg} / \mathrm{ha} \\
\text { depending on variety and } \\
\text { stage of wilting }(33,300 \\
\text { cuttings of } 25-30 \mathrm{~cm})\end{array}$ \\
\hline $\begin{array}{l}\text { Storability of } \\
\text { harvested seed }\end{array}$ & Up to 1 year & Up to 6 months & 2-3 days \\
\hline $\begin{array}{l}\text { Seed cost (USD/ } \\
\text { ha) }\end{array}$ & $\begin{array}{l}\text { USD16 to } \\
\text { USD27 }\end{array}$ & $\begin{array}{l}\text { Up to } 50-70 \% \text { of the total } \\
\text { production cost }{ }^{\mathrm{c}} \text { : } \\
\text { USD2,527/ha }\left(\text { Chile }^{\mathrm{d}}\right) \text {; } \\
\text { USD818/ha }\left(\text { Idaho }^{\mathrm{e}}\right) ; \\
\text { USD1090/ha }\left(\text { Peru }^{\mathrm{f}}\right)\end{array}$ & $\begin{array}{l}\text { Highly variable. For } \\
\text { Tanzania: USD2 bundle of } \\
300 \text { vines ( } 900 \text { cuttings), } \\
\text { circa USD76/ha }\end{array}$ \\
\hline $\begin{array}{l}\text { Main pest and } \\
\text { diseases causing } \\
\text { seed } \\
\text { degeneration }\end{array}$ & $\begin{array}{l}\text { Seed degeneration } \\
\text { is due to } \\
\text { contamination by } \\
\text { pollen from other } \\
\text { varieties }\end{array}$ & $\begin{array}{l}\text { Potato virus X, potato virus } \\
\text { Y, potato leafroll virus, } \\
\text { Ralstonia, Rhizoctonia, } \\
\text { Pectobacterium, } \\
\text { Spongospora, Globodera, } \\
\text { Meloidogyne, Tecia, } \\
\text { Symmetrischema, } \\
\text { Phthorimaea, etc. }{ }^{\text {c }}\end{array}$ & $\begin{array}{l}\text { Viruses: a complex } \\
\text { sweetpotato chlorotic stunt } \\
\text { virus and sweetpotato } \\
\text { feathery mottle virus } \\
\text { transmitted by whitefly and } \\
\text { aphids. Weevils also } \\
\text { damage and are transmitted } \\
\text { through seed, namely } \\
\text { Cylas brunneus and } C \text {. } \\
\text { puncticollis }\end{array}$ \\
\hline
\end{tabular}

Adapted from Bentley et al. (2016)

${ }^{a}$ USD0.80-USD1.00/kg for open-pollinated subsidized maize in Nigeria, USD1.33/kg for privatesector hybrid (Mele and Guéi 2011). Certified maize seed is sold for roughly the same price in Peru, according to the INIA website www.inia.gob.pe/prod-servicios/semillas

${ }^{\mathrm{b}}$ Struik and Wiersema (1999)

'Thomas-Sharma et al. (2016)

${ }^{\mathrm{d}}$ Ministerio de Agricultura de Chile (2013) 1 USD = 554 Chilean pesos

'Patterson (2014)

fVictor Suárez, personal communication. Varieties Canchán and Yungay in Julcán province, La Libertad department in 2013. 1 USD = 2.75 Peruvian Sol

${ }^{\mathrm{g}} \mathrm{Kwame}$ Ogero, personal communication

tuberisation (Haverkort and Harris 1987). However, highland farmers are at risk of unpredictable rainfall and increasing temperatures caused by climate change and variability that affect farm productivity under rain-fed conditions. Potato growing is highly susceptible to precipitation variation and $575 \mathrm{~mm}$ is the minimum rainfall required per cropping season to obtain reasonable yields of $20 \mathrm{t} / \mathrm{ha}$. Erratic rainfall in Kenya during the 2016-2017 drought reduced yields obtained by seed potato multipliers by $56 \%$, from 15 to $7 \mathrm{t} / \mathrm{ha}$. This was after a reduction in rainfall from a 
seasonal mean of 737 to $126 \mathrm{~mm}$ (International Potato Center 2017a). Potential future impacts of climate change will exacerbate this trend (Zemba et al. 2013).

In Kenya, certified seed production meets approximately $5 \%$ of demand, which has slowly increased from $0.6 \%$ in 2009 (International Potato Center 2016). The majority of farmers obtain seed from informal sources or save a portion of their harvest as seed for several generations. This is the case in most potato-producing countries in SSA, where certification protocols are not put into practice. The low yields plaguing this region (8-15 t/ha compared to realistic yields of 20-30 t/ha obtainable under smallholder farmer conditions) are largely a consequence of farmers' limited access to quality seed of biotic and abiotic stress tolerant climate-smart varieties (Demo et al. 2015).

\subsubsection{Climate-Smart Varieties}

Climate change can be a major threat to potato production systems in Africa. In many of the drier potato growing regions, climate change causes yields to decline as a result of water and heat stress. Yields will decrease even further where there is no possibility of irrigation, to the extent that growing potatoes will become impossible. Traditional potato growing areas are also at risk of increasing temperatures; hence varieties need to be heat tolerant. To adapt the potato to overcome these challenges, breeding efforts by CIP prioritize resilience to the most likely future abiotic and biotic stresses: heat tolerance, water use efficiency, earliness and disease tolerance. In a series of adaptive participatory trials in several SSA countries, some climatesmart potato clones have shown great adaptability to erratic weather conditions. With 15-20\% less precipitation and a temperature increase of $2-3{ }^{\circ} \mathrm{C}$ under the scenarios of climate change, these clones have shown greater tolerance to drought and heat without yield losses (International Potato Center 2017b). This reduces the risk of yield losses due to climate change, and offers farmers in mid-altitude regions the possibility to integrate potato into their agrifood system.

From 2013 to 2015, 15 clones were evaluated for water-stress tolerance over three seasons (2013-2015) at three locations ranging from 1300 to 1700 masl, where seasonal precipitation averaged $295 \mathrm{~mm}$ (range $210-414 \mathrm{~mm}$ ) and yielded significantly greater than the existing varieties (Table 9.2, International Potato Center 2017b). In 2016 and 2017, five of these biotic and abiotic-stress tolerant clones with water-stress tolerance and enhanced resistance to late blight and viral diseases were officially released in Kenya, specifically: Unica, Lenana, Wanjiku, Chulu and Nyota.

\subsubsection{Complexity of the Seed Potato Production System}

Seed potato goes through physiologically different forms and rounds of bulking before arriving at the final product. The first generation (G0) is the product of tissue culture (TC) plantlets (the foundation and conservation material) in the laboratory. 
Table 9.2 Performance of potato clones in water stressed conditions at average precipitation of $295 \mathrm{~mm}$ (range from 210 to $414 \mathrm{~mm}$ ) across three seasons and three locations between 1300 and 1700 masl in Kenya

\begin{tabular}{l|l|l}
\hline $\begin{array}{l}\text { Cluster by \% age above mean of existing } \\
\text { varieties }\end{array}$ & Yield t/ha & Number of clones \\
\hline Greater than $40 \%$ & 22.9 & 1 \\
\hline Greater than $30 \%$ & 20.7 & 5 \\
\hline Greater than $20 \%$ & 19.4 & 5 \\
\hline Greater than $10 \%$ & 18.3 & 4 \\
\hline Mean of existing varieties & 15.5 & \\
\hline
\end{tabular}

The TC plantlets are transferred to a screen-house to produce minitubers (G1) using sand hydroponics or aeroponics. The minitubers are then planted in the field to produce G2 seed in standard seed sizes. The next phase in the seed production process involves bulking tubers. After two to three generations of field multiplication, the seed can be certified. In those countries without operational certification systems, seed multipliers obtain starter material from the National Agricultural Research System (NARS). Informal systems rely on seed multipliers multiplying certified seed for an additional one or two seasons to make quality seed locally available to farmers (Fig. 9.1).

The seed potato planting rate is $2 \mathrm{t} / \mathrm{ha}$ and seeds are often sold at farm gates, which means the expansion of improved seed systems is vital to ensuring farmers can access quality seed. Agro-dealers do not distribute seed potato due to its bulk and perishability, and few businesses have invested in certified seed because of high resource and human capacity requirements. To fill the gap in the supply of quality seed at the local level, informal seed multipliers (ISM) are now beginning to diversify.

\subsubsection{Diversifying Seed Potato Systems}

The supply of certified seed in Kenya is limited, therefore many farmers use unmarketable ware potatoes as seed, which they source either on farm or from local markets. This perpetuates the cycle of low yields, as there is no input of quality seed to flush out the diseased (Bentley et al. 2016). To improve localised access to quality seed, ISM in four Kenyan counties (Elgeyo-Marakwet, Nandi, Meru and Uasin Gishu counties) were trained in seed potato multiplication, quality control and record keeping, to support their seed production businesses. The ISMs invested in certified seed potato as starter material which would then multiply. Their transport costs were covered initially, and reduced as the ISM's businesses developed.

In the first 18 months, 220 ISM sold 322 tonnes of quality seed, enough for 1700 farmers to plant 160 ha. The ISM's mean gross margins over three seasons of seed potato sales ranged from 2000 to $4000 \mathrm{USD} / \mathrm{ha}$ (International Potato Center 2017c).

Establishing these ISM seed businesses also greatly benefitted the farmers, who travelled significantly shorter distances (reduced from 110 to $3 \mathrm{~km}$ ) to access qual- 


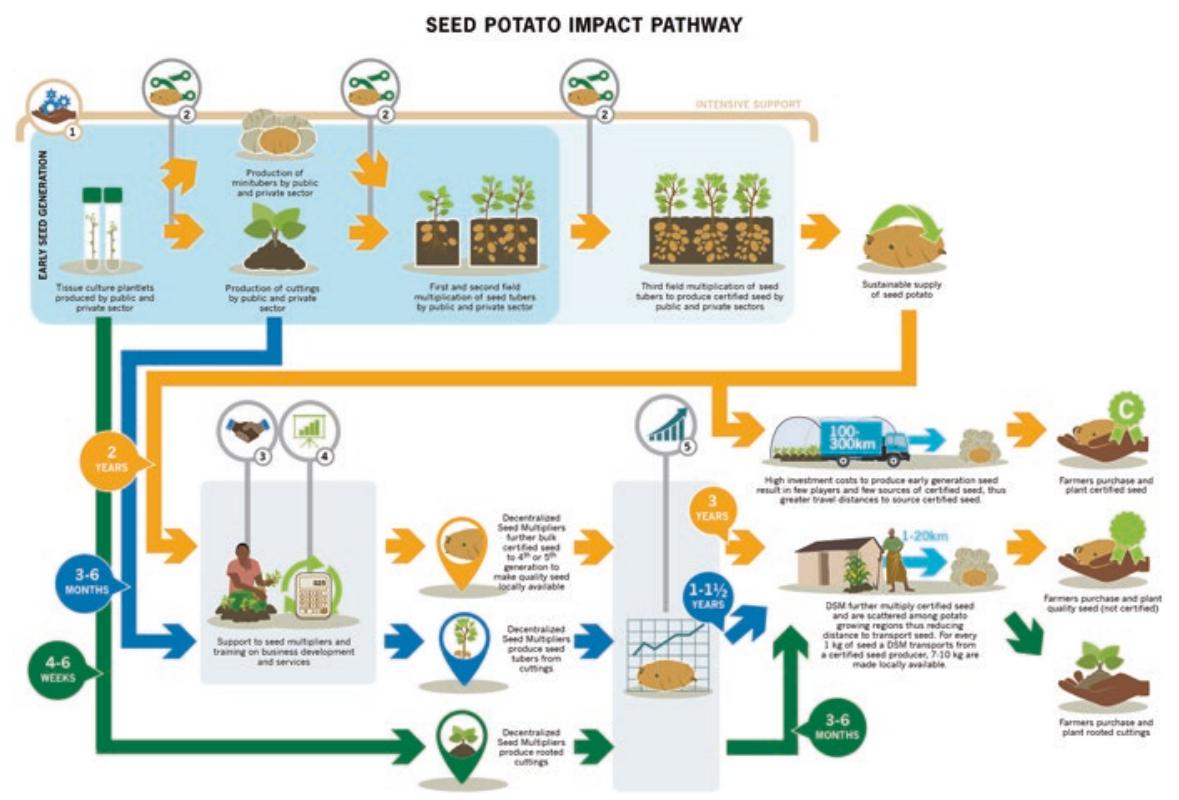

Fig. 9.1 Seed potato production system showing diverse entry and exit points to engage in seed production that suits various farmer and entrepreneurial profiles

ity, certified seed in Kenya (International Potato Center 2017c). In Meru, the preliminary data also showed that farmers are benefitting from the ISM. Their yields doubled after just one season using the quality seed, averaging $19.2 \mathrm{t} / \mathrm{ha}$ compared to $9.4 \mathrm{t} / \mathrm{ha}$ using traditional seed (unpublished data).

\subsubsection{Using Apical Cuttings to Boost Potato Seed Systems}

An apical cutting is similar to a nursery-grown seedling, except that it is produced through vegetative means. Rather than allowing TC plantlets to mature and produce minitubers in the screen-house, apical cuttings are produced from the plantlets. Once rooted, the cuttings are planted in the field to produce field seed tubers, followed by one to three successive generations of field multiplication.

In current production systems, apical cuttings can be used in place of minitubers (Bryan 1981). While the latter are more versatile-minitubers can be stored until planting and are easy to transport—apical cuttings are more productive and reduce the time needed to complete the production cycle by one season.

Using apical cuttings in seed systems is a relatively new concept in Kenya, gaining acceptance among stakeholders largely due to productivity gains over seed systems that use minitubers. Within 1 year of the initial trial to test the performance of apical cuttings in the field, two private sector enterprises have invested in producing 
Table 9.3 Season 2 on-farm assessment of productivity of apical cuttings to produce seed potato tubers

\begin{tabular}{l|l|l}
\hline Variety/spacing & $\begin{array}{l}\text { Mean \# } \\
\text { tubers/cutting }\end{array}$ & $\begin{array}{l}\text { Mean \# tubers } \\
>20 \mathrm{~mm} / \text { cutting }\end{array}$ \\
\hline Dutch Robyjin $^{\mathbf{a}}$ & $\mathbf{1 2 . 0}$ & $\mathbf{1 0 . 4}$ \\
\hline $15 \times 20$ & 10.7 & 8.6 \\
\hline $20 \times 25$ & 9.3 & 8.0 \\
\hline $75 \times 30$ & 16.1 & 14.6 \\
\hline Tigoni & $\mathbf{1 7 . 0}$ & $\mathbf{1 5 . 6}$ \\
\hline $15 \times 20$ & 13.4 & 11.8 \\
\hline $20 \times 25$ & 15.2 & 13.9 \\
\hline $75 \times 30$ & 22.4 & 21.1 \\
\hline Unica & $\mathbf{9 . 5}$ & $\mathbf{8 . 8}$ \\
\hline $15 \times 20$ & 7.7 & 7.3 \\
\hline $20 \times 25$ & 8.2 & 7.7 \\
\hline $75 \times 30$ & 12.5 & 11.6 \\
\hline
\end{tabular}

${ }^{\mathrm{a}}$ Highlighted rows are mean tuber yield for the variety across all spacings

them, and the seed potato unit at the National Potato Program has adopted the technology into their seed production system. The body that regulates seed certification has also endorsed apical cuttings and is integrating the technology into seed potato certification protocol.

Progressive farmers and ISM hosted two trials to assess the productivity of apical cuttings over two seasons. This was the first time after one on-station trial to assess productivity, and while the results from the first season were highly variable, they mostly achieved the expected multiplication rate of eight tubers/cutting (data not presented).

Productivity improved from season one to season two, with the mean tuber multiplication rate surpassing the target of eight tubers $>20 \mathrm{~mm} /$ cutting, averaging 8.8 15.6 tubers $>20 \mathrm{~mm} /$ cutting (Table 9.3).

\subsubsection{Productivity Obtained by Informal Seed Multipliers}

Additionally, 40 ISM trialed cuttings to produce seed potato. In their first season of production, ISM yields surpassed the expected eight tubers/plant (Table 9.4).

High rates of productivity (between 8 and 10 and up to 15+ tubers per cutting) means seed sales from the cuttings can become profitable after two seasons of multiplication and farmers can access earlier generation seed. Seed tubers produced from cuttings can also be multiplied on farm for a further few seasons without risking significant seed degeneration, provided good agricultural practices are followed. 
Table 9.4 Productivity seed potato tubers from apical cuttings obtained by informal seed multipliers (ISM) in their first season of production

\begin{tabular}{l|l|l|l|r}
\hline Mean number of tubers/cutting & & \\
\hline Variety & Kibiricha network & Kiirua network $^{\mathrm{a}}$ & Nkuene network $^{\mathrm{b}}$ & Abothoguchi network $^{\mathrm{c}}$ \\
\hline Tigoni & 11.9 & 8.3 & $11.0(8.2-13.8)$ & $8.1(4.2-13.1)$ \\
\hline Unica & 22.9 & 18.4 & - & $7.4(2.5-13.0)$ \\
\hline Konjo & 25.5 & 24.1 & $14.1(10.2-19.9)$ & - \\
\hline Dutch Robyn & 13.0 & 9.1 & - & -
\end{tabular}

${ }^{\mathrm{a}}$ Data are mean of 10 ISM between the two networks

${ }^{b}$ Brackets are minimum and maximum values among 12 ISM

'Brackets are minimum and maximum values among 13 ISM

\subsubsection{Adapting Sweetpotato Varieties and Seed Systems Combatting Drought and Food Insecurity in Mozambique}

Mozambique has experienced 13 significant drought years between 1979 and $2016^{1}$ and represents the challenge across much of SSA, where an estimated 2.3 million people needed humanitarian assistance between January and March 2017 (FSIN 2017). Levels of chronic undernutrition are high among children under five in the region, with 71.2\% estimated to be vitamin A deficient (VAD) (Aguayo et al. 2005).

High levels of VAD in young children prompted researchers to introduce betacarotene rich sweetpotato into Mozambique in the late 1990s, because one root (125 g) of an OFSP variety can meet a young child's daily vitamin A needs (Low et al. 2017). Sweetpotato (Ipomoea batatas L.) has long been a staple in Mozambique, but the dominant varieties are white-fleshed with no beta-carotene, which the body converts into vitamin A. Initial efforts focused on testing contending varieties from around the world, resulting in the release of nine OFSP varieties in 2000. In 2002 these varieties were widely distributed in southern Mozambique as a post-flood disaster recovery initiative. They performed well in southern and central Mozambique until three seasons of consecutive drought hit in 2005.

Among the most popular of these first-generation varieties was the Americanbred Resisto, which outyielded local varieties, matured earlier (at 4 months), had a deep orange flesh, moderate dry matter (24\%) and the smooth oblong shape favoured by marketers. In the dry season, when farmers plant a second crop in valley bottoms with residual moisture. Resisto produced more roots than the dominant, reputedly drought tolerant local variety Canasumana, but it had no vines left at the time of harvest. In contrast, Canasumana had abundant foliage left (Low et al. 2001). In tropical areas, sweetpotato is largely propagated from vine cuttings of the previous crop, therefore not maintaining sufficient quantities of vigorous vines resulted in a shortage of Resisto planting material the following season.

\footnotetext{
${ }^{1}$ Significant drought in parts of the country in 1979, 1981, 1987, 1990, 1998, 2001, 2005, 2007, 2008, 2010, 2015, 2016.
} 
In recognition that OFSP was well liked by the population, especially young children, but that better adapted varieties were needed, funds were raised to support breeding in Mozambique. As over 50\% of sweetpotato production was lost (both white- and orange-fleshed) in the prolonged 2005 drought, the first step was to collect all landraces throughout the country that had survived. In total, 147 accessions (both landraces and improved materials) were characterized morphologically and molecularly. The best (in terms of high yield performance under water-stressed and non-water stressed condition) were selected as parents to develop drought-tolerant OFSP.

Breeding varieties to survive drought is a complex process. Drought can occur at any point in the development cycle of the crop, and the varieties selected need to perform well under water-stressed and non-water stressed conditions (Andrade et al. 2016a; Makunde et al. 2017). For a variety to be permanently adopted, it needs to have vigorous vines and roots left in the ground at harvest (a traditional source of planting material) must sprout well at the beginning of the rains. With regards to taste, a floury texture is preferred, a characteristic associated with dry matter contents of $28 \%$ or above.

The standard protocol historically used for many sweetpotato breeding programs required a variety to develop over a period of 8 years, including: the crossing of the new parents and generation of seed; the growing out of clones from those seeds; a selection process over a number of years, specifically evaluating the variety's agronomic and organoleptic characteristics with active farmer participation. The Accelerated Breeding Scheme (ABS), unlike this traditional approach, exploits the fact that each clone is a potential variety and has more sites earlier in the breeding cycle, including one stress environment for the trait of interest (in this case a drought-prone site). The ABS reduces the breeding cycle from 8 to 4-5 years (Grüneberg et al. 2015).

By applying the ABS, 15 new drought-tolerant OFSP varieties were released in Mozambique in 2011 (Andrade et al. 2016b). An additional four OFSP varieties were released in 2016 (Andrade et al. 2016c). Some of these varieties have widelyadapted and others performed well in specific agroecologies with a range of maturity periods. Many farmers prefer the six improved early-maturing varieties, which are ready in 3-4 months, because they enable them to manage rainy seasons of unpredictable lengths (Alvaro et al. 2017). Some of the later maturing varieties are deeper rooting which can be advantageous, because when the soil dries and cracks, weevils can reach the roots and the deeper the root, the harder it is for the weevil to reach it (Low et al. 2009).

There is strong evidence to suggest that combining OFSP introduction with community-level nutrition education increases the intake of vitamin A in young children and their mothers, and reduces VAD in children under 5 years of age (Low et al. 2007; Hotz et al. 2012; Brauw et al. 2013). However, a major challenge in drought prone areas has been ensuring quality planting material is available when the rains begin (Fig. 9.2). In bimodal areas, vine retention is not a major issue because farmers often use cuttings from an existing crop to start a new one. This explains the larger per capita production of sweetpotato in East and Central Africa 


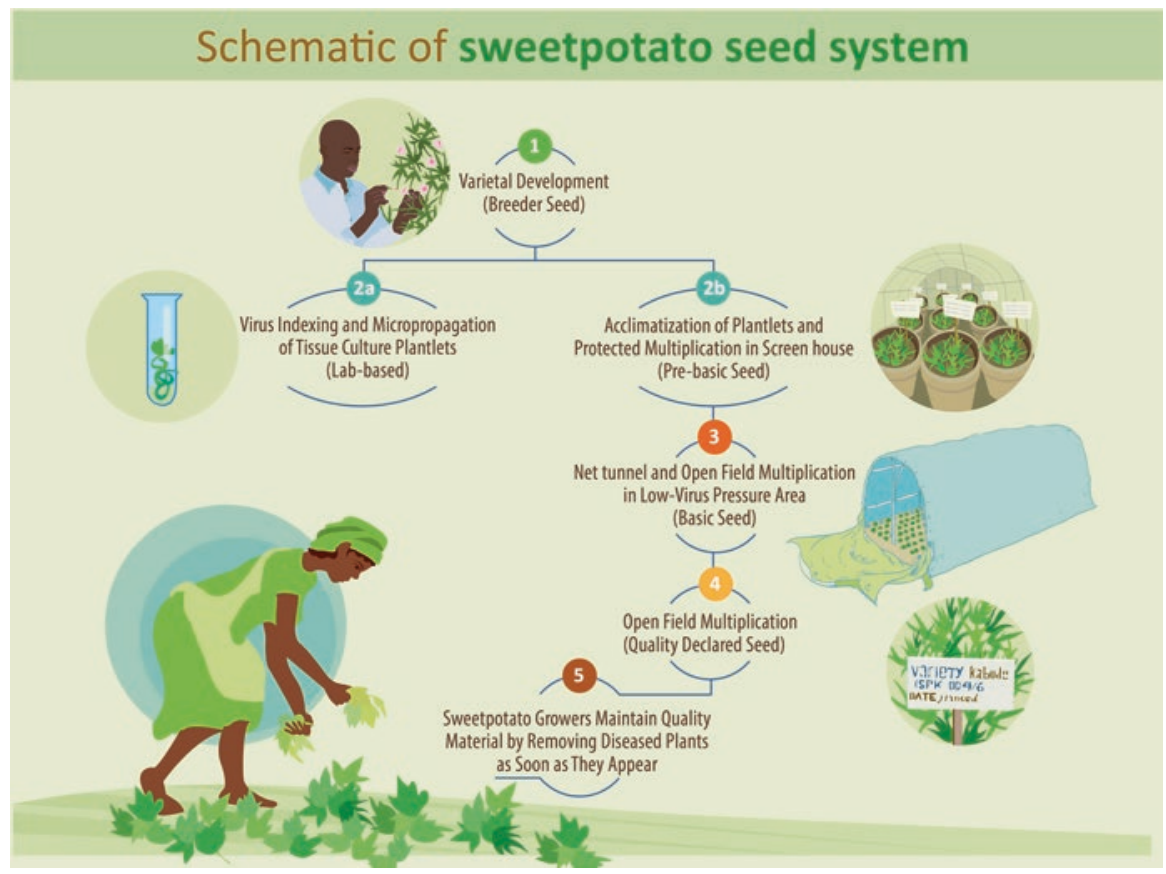

Fig. 9.2 Steps to produce sweetpotato seed

than in unimodal Southern Africa. In drought-prone areas, some farmers with access to valley bottoms with residual moisture use this land for a second crop. Other farmers water small plots near their homes, and some invest in irrigation. The most common method, however, is to leave roots in the ground, ready to sprout when the rains start. The drawback is that the roots are often attacked by weevils or other diseases, which reduces both the quantity and quality of subsequent root output (Gibson et al. 2011).

A method known as Triple S (Storage in Sand and Sprouting) improves upon this traditional practice. Developed in drought-prone areas of Uganda, the method selects pest-free roots at harvest, layers them in a container of sand and stores them in the home for up to 7 months. Some 6-8 weeks before the rains are expected to start, the sprouted roots are planted in a nursery and watered twice a week, producing approximately 40 cuttings per root. Being ready to plant when the rains begin, they enable yield gains ranging from 25\% to 300\% (Namanda et al. 2013). This technology is now being adapted to local conditions and promoted in six other countries, including Mozambique. It is a low-cost, knowledge-based technology that enables farmers to adapt to drought, and the technique can also be used to store larger roots for consumption for an additional 2-4 months. 


\subsection{Implications for Development}

As described in the potato and sweetpotato case studies, adapting smallholder farming to climate change can be achieved by growing varieties that can cope with high temperatures, erratic rainfall patterns, and even drought. However, functional seed systems are essential for delivering such varieties and providing healthy seed. Research is revolutionizing this adaption to climate change, from new breeding approaches (e.g. ABS), multiplication techniques (e.g. apical cuttings) and on-farm seed management techniques (e.g. Triple S), to new approaches for engaging with specialized seed producers, seed users, markets and regulatory agencies. The clear links between climate change, improved varieties and seed systems illustrate the importance of interdisciplinary collaborations to ensure that scientific, technical, socio-economic and gender aspects are considered in such interventions.

Given the need for strict quality control to manage the high risk of seed degeneration in VPCs, developing seed systems to deliver climate-smart varieties requires a multi-stakeholder approach, especially if support for a project is limited. Sustaining seed systems beyond project life is a key challenge that can be addressed through well-targeted partnerships that drive the process while supporting those who use the system with the technologies to deliver them.

\section{References}

Aguayo VM, Kahn S, Ismael C, Meershoek S (2005) Vitamin A deficiency and child mortality in Mozambique. Public Health Nutr 8(1):29-31. https://doi.org/10.1079/PHN2004664

Alvaro A, Andrade MI, Makunde GS, Dango F, Idowu O, Grüneberg W (2017) Yield, nutritional quality and stability of orangefleshed sweetpotato cultivars successively later harvesting periods in Mozambique. Open Agric 2(1):464-468. De Gruyter Open. https://doi.org/10.1515/ opag-2017-0050

Andrade MI, Naico A, Ricardo J, Eyzaguirre R, Makunde GS, Ortiz R, Grüneberg WJ (2016a) Genotype $\times$ environment interaction and selection for drought adaptation in sweetpotato (Ipomoea Batatas [L.] Lam.) in Mozambique. Euphytica 209(1):261-280. https://doi. org/10.1007/s10681-016-1684-4

Andrade MI, Ricardo J, Naico A, Alvaro A, Makunde GS, Low JW, Gruneberg WJ (2016b) Release of orange-fleshed sweetpotato (Ipomoea batatas [1.] Lam.) cultivars in Mozambique through an accelerated breeding scheme. J Agric Sci:1-11. https://doi.org/10.1017/S002185961600099X

Andrade MI, Alvaro A, Menomussanga J, Makunde GS, Ricardo J, Grüneberg WJ, Eyzaguirre R, Low J, Ortiz R (2016c) 'Alisha', 'Anamaria', 'Bie', 'Bita', 'Caelan', 'Ivone', 'Lawrence', 'Margar ete', and 'Victoria'Sweetpotato. Hortscience 51(5):597-600

Bentley J et al (2016) Case Studies of Roots, Tubers and Banana Seed Systems. https://doi.org/10 .4160/23096586RTBWP20163

de Brauw A, Eozenou P, Gilligan D O, Hotz C, Kumar N, Meenakshi JV (2013) Biofortification, crop adoption and health information: impact pathways in Mozambique and Uganda. In: Agricultural and Applied Economics Association, 2013 annual meeting, August 4-6, 2013, Washington, D.C. https://doi.org/10.13140/2.1.1751.4243

Bryan J et al (1981) 'Single-Node Cuttings: A Rapid Multiplication Technique for Potatoes.', in Rapid Multiplication Techniques. International Potato Center (CIP), Lima, Peru (CIP slide training series, I), p. 10pp 
Chile MA (2013) Ficha Técnico-Económica de Papa de Guarda

Demo P, Lemaga B, Kakuhenzire R, Schulz S, Borus D, Barker I, Woldegiorgis G, Parker ML, Schulte-Geldermann E (2015) Strategies to improve seed potato quality and supply in SubSaharan Africa: experience from interventions in five countries. In: Potato and sweetpotato in Africa: transforming the value chains for food and nutrition security, DABI, Wallingford, pp $155-67$

FAOSTAT (2017) 2017. http://www.fao.org/faostat/en/\#home

FSIN (2017) Food Security Information Network (FSIN) -Home. 2017. http://www.fsincop.net/

Gibson RW, Namanda S, Sindi K (2011) Sweetpotato seed systems in East Africa. Afr Crop Sci Conf Proc 10:449-451

Gildemacher PR, Demo P, Barker I, Kaguongo W, Woldegiorgis G, Wagoire WW, Wakahiu M, Leeuwis C, Struik PC (2009) A description of seed potato systems in Kenya, Uganda and Ethiopia. Am J Potato Res 86(5):373-382. https://doi.org/10.1007/s12230-009-9092-0

Grüneberg WJ, Ma D, Mwanga ROM, Carey EE, Huamani K, Diaz F, Eyzaguirre R et al (2015) Advances in sweetpotato breeding from 1992 to 2012. In: Potato and sweetpotato in Africa: transforming the value chains for food and nutrition security. CABI, Wallingford, pp 3-68. https://doi.org/10.1079/9781780644202.0003

Haverkort AJ, Harris PM (1987) A model for potato growth and yield under tropical highland conditions. Agric For Meteorol 39(4):271-282. Elsevier. https://doi. org/10.1016/0168-1923(87)90020-7

Hotz C, Loechl C, De Brauw A, Eozenou P, Gilligan D, Moursi M, Munhaua B, Van Jaarsveld P, Carriquiry A, Meenakshi JV (2012) A large-scale intervention to introduce orange sweet potato in rural Mozambique increases vitamin A intakes among children and women. Br J Nutr 108(1):163-176. https://doi.org/10.1017/S0007114511005174

International Potato Center (2016) The status of potato value chains in Kenya. International Potato Center, Lima, Peru

International Potato Center (2017a) Accelerated value chain development program. Root crops quarter 3 of year 2 report, International Potato Center, Lima, Peru

International Potato Center (2017b) Evaluation and selection of heat and drought tolerance of CIP potato germplasm, International Potato Center, Lima, Peru

International Potato Center (2017c) Feed the future Kenya, accelerated value chain development program root crops year 2 annual report. International Potato Center, Lima, Peru

Low JW, Arimond M, Osman N, Osei AK, Zano F, Cunguara B, Selemane M L, Abdullah D, Tschirley D (2001) Towards sustainable nutrition improvement in rural Mozambique: addressing macro- and micro-nutrient malnutrition through new cultivars and new behaviors. Pdfs.semanticscholar.org, Michigan State University, pp 1-40

Low JW, Arimond M, Osman N, Cunguara B, Zano F, Tschirley D (2007) A food-based approach introducing orange-fleshed sweetpotatoes increased vitamin A intake and serum retinol concentrations in young children in rural Mozambique. J Nutr 137(5):1320-1327. Drop American Society for Nutrition

Low J, Lynam J, Lemaga B, Crissman C, Barker I, Thiele G, Namanda S, Wheatley C, Andrade M (2009) Sweetpotato in Sub-Saharan Africa. In: The sweetpotato. Springer Netherlands, Dordrecht, pp 359-390. https://doi.org/10.1007/978-1-4020-9475-0_16

Low JW, Mwanga ROM, Andrade M, Carey E, Ball A-m (2017) Tackling vitamin A deficiency with biofortified sweet potato in Sub-Saharan Africa. Glob Food Sec 14:23-30

Makunde GS, Andrade MI, Ricardo J, Alvaro A, Menomussanga J, Gruneberg W (2017) Adaptation to mid-season drought in a sweetpotato (Ipomoea Batatas [L.] Lam) germplasm collection grown in Mozambique. Open Agric 2(1). https://doi.org/10.1515/opag-2017-0012

Namanda S, Amour R, Gibson RW (2013) The triple S method of producing sweet potato planting material for areas in Africa with long dry seasons. J Crop Improv 27(1). Taylor \& Francis Group):67-84. https://doi.org/10.1080/15427528.2012.727376

Patterson PE (2014) 2014 Cost of Potato Production for Idaho With Comparisons to 2013. University of Idaho 
RTB (2016) RTB CGIAR research program on root, tubers and bananas. Proposal 2017-2022. Lima: CIP III (July 2016)

Struik PC, Wiersema SG (1999) Seed potato technology. Wageningen University Press, Wageningen Thiele G, Khan A, Heider B, Kroschel J, Harahagazwe D, Andrade M, Bonierbale M et al (2017) Roots, tubers and bananas: planning and research for climate resilience. Open Agric 2(1). https://doi.org/10.1515/opag-2017-0039

Thomas-Sharma S, Abdurahman A, Ali S, Andrade-Piedra JL, Bao S, Charkowski AO, Crook D et al (2016) Seed degeneration in potato: the need for an integrated seed health strategy to mitigate the problem in developing countries. Plant Pathol 65(1):3-16. https://doi.org/10.1111/ ppa.12439

Van Mele P, Bentley JW, Guei RG (2011) African Seed Enterprises: Sowing the Seeds of Food Security. Wallingford, UK: CAB International

Zemba AA, Wuyep SZ, Adebayo AA, Jahknwa CJ (2013) Growth and yield response of Irish potato (Solanum Tuberosum) to climate in Jos-South, Plateau State, Nigeria. Global J Hum Soc Sci 13(5):13-18

Open Access This chapter is licensed under the terms of the Creative Commons Attribution 4.0 International License (http://creativecommons.org/licenses/by/4.0/), which permits use, sharing, adaptation, distribution and reproduction in any medium or format, as long as you give appropriate credit to the original author(s) and the source, provide a link to the Creative Commons license and indicate if changes were made.

The images or other third party material in this chapter are included in the chapter's Creative Commons license, unless indicated otherwise in a credit line to the material. If material is not included in the chapter's Creative Commons license and your intended use is not permitted by statutory regulation or exceeds the permitted use, you will need to obtain permission directly from the copyright holder.

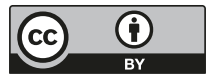

